\title{
Hydrodynamic and loss of life modelling for the 1953 Canvey Island flood
}

Manuela Di Mauro \& Darren Lumbroso

Reproduced from:

Flood Risk Management - Research and Practice

Proceedings of FLOODrisk 2008

Keble College, Oxford, UK

30 September to 2 October 2008 


\title{
Hydrodynamic and loss of life modelling for the 1953 Canvey Island flood
}

\author{
Manuela Di Mauro \& Darren Lumbroso \\ HR Wallingford Ltd, Wallingford, Oxfordshire, UK
}

\begin{abstract}
Canvey Island is located in the Thames Estuary. The island is a low-lying alluvial fan covering an area of $18.5 \mathrm{~km}^{2}$, with an average height of approximately $1 \mathrm{~m}$ below the mean high water level. Canvey Island is protected against inundation by a network of flood defences. In 1953, the island was inundated by the "Great North Sea Flood" that breached the island's flood defences and resulted in the deaths of 58 people and the destruction of several hundred houses. As part of the EC funded research project FLOODsite, work was undertaken to set up both a hydrodynamic and an agent-based loss-of-life model of Canvey Island for the 1953 flood. The objective of the work was to obtain a better understanding of the 1953 flood event and to analyse the consequences of breaches in the island's flood defences in terms of loss of life and injuries. The work undertaken indicates that the agent-based life safety model can provide a scientifically robust method to assess loss of life, injuries and evacuation times for areas that are at risk from flooding in the UK.
\end{abstract}

\section{INTRODUCTION}

Canvey Island is an island in the Thames Estuary, covering an area of $18.5 \mathrm{~km}^{2}$. It is formed on a flat, low-lying alluvial fan that has an average height of approximately $1 \mathrm{~m}$ below the mean high water level. The location of Canvey Island is shown in Figure 1. Canvey Island is protected from the sea by a network of flood defences. In 1953, the island was inundated by the "Great North Sea Flood" that breached the island's flood defences and resulted in the deaths of 58 people and the destruction of several hundred houses. The consequences of the 1953 floods led to the construction of new flood defences (Brown et al, 2007).

A concrete wall rising approximately $3 \mathrm{~m}$ to $4 \mathrm{~m}$ above the mean high water mark currently surrounds Canvey Island. In 1953 Canvey Island was relatively developed with some 5,200 houses on the island below the normal high tide level. The lowest part of the island lies at the centre of the island creating a bowl effect. All surface water drainage has to be pumped over the sea wall. Access to Canvey Island is currently only possible by two roads both of which are connected to the same roundabout. Any disruption to these routes would hamper evacuation and severely limit access. The likelihood of flooding of the access routes to and from Canvey Island will increase as a result of the continuing rise in sea levels as a result of climate change. Currently on Canvey Island, it has been estimated that $30 \%$ of properties are bungalows and $45 \%$ of flats are situated at ground floor level (Kelman, 2002). There is thus a large risk to life and property with limited opportunities to temporarily move to a higher level.

As part of the EC research project FLOODsite, work was undertaken to set up a hydrodynamic and a loss-of-life model of the 1953 flood for Canvey Island. The objectives of the work were:

- To obtain a better understanding of the 1953 flood event;

- To analyse the consequences of breaches in the island's flood defences in terms of loss of life and injuries;

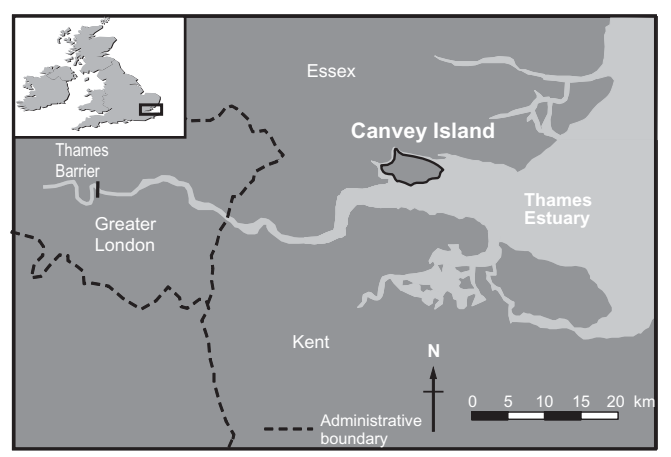

Figure 1. Location of Canvey Island. 
- To assess the results provided by an agent-based loss of life model where the receptors dynamically interact with the flood wave.

This paper describes the results of the reconstruction of the 1953 flood event and the implementation of loss-of-life model that dynamically simulates each individual person at risk from flooding.

\section{BACKGROUND TO THE 1953 FLOOD}

The 1953 flood was caused by a storm surge, that has been described as 'the worst peacetime disaster that the UK has known'. The tidal surge reached Canvey Island at around $1.00 \mathrm{am}$ in the morning on Sunday 1 February 1953 and around this time the first breach of the flood defences happened. In 1953 there was no accurate tidal surge forecasting system in place and there was no single body responsible for flood warnings. Canvey Island archive web site states site that "whilst communities did have emergency plans, many telephone lines had been brought down by the gales and affected by the flooding, so large scale evacuations were not possible. As a consequence virtually no warning of the impending disaster was received at Canvey Island until it was too late. Under a plan termed Operation King Canute the fire brigade were sent out to alert the people of Canvey. At the same time the siren and fore maroons were sounded in such a way that it was hoped islanders would become curious enough to get out of bed to look outside. Fortunately some did and were evacuated; others were soundly sleep and did not hear anything above the howling winds. They either woke up much later when the icy water lapped over them, or sadly never woke up at all. Many of the victims were in the holiday bungalows in the eastern Newlands part of the island and perished as the water reached ceiling level". Figure 2 shows a view of Canvey Island looking out to sea from the mainland taken a week after the flood occurred.

\section{BACKGROUND TO THE MODELLING OF THE 1953 FLOOD}

\subsection{Introduction}

In order to model the 1953 Canvey Island flood a historical analysis was undertaken to establish the situation, in terms of source, pathways and receptors that existed at that time. Important sources of in-formation included:

- Historical maps of the island;

- Articles from 1953 newspapers;

- Police reports;
- Information from HR Wallingford's archives;

- The Essex life in film archive;

- The results of physical modelling of the Thames Estuary carried out in 1954.

This information was used to assist in assessing the height and location of the 1953 flood defences, to produce a digital terrain model, to reconstruct the tidal shape, to assess the incoming flood volume, and to establish the number and location of people on the island when the flood occurred.

The modelling of the 1953 flood was undertaken in two stages as follows:

1. Hydrodynamic modelling of the 1953 flood to estimate the water depths and velocities as the event unfolded;

2. Loss-of-life modelling using a dynamic agentbased model.

These two stages are described below.

\subsection{Hydrodynamic modelling of the 1953 flood event}

\subsubsection{Background}

A two dimensional hydrodynamic model of Canvey Island was set up using the finite difference hydrodynamic software TUFLOW. It was necessary to use a two dimensional model to obtain the spatiotemporal variation of the water depth and velocity as the 1953 event unfolded. The ground elevation information used in the model was taken from a recently under-taken Light Detection and Ranging (LIDAR) topographic survey data. Owing to the fact

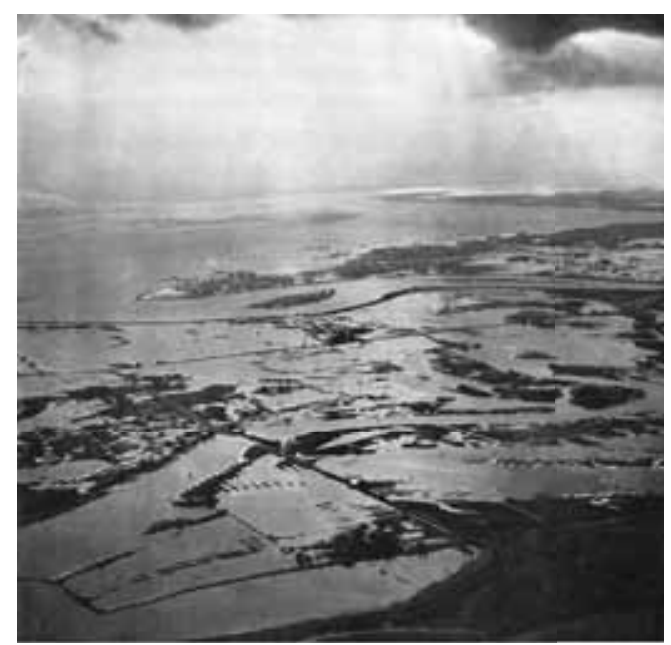

Figure 2. Photograph of the Canvey Island flood taken on 8 February 1953. (Source: Canvey Island archive site, 2008). 
that there was no topographic data readily available for the island dating from 1953 work needed to be undertaken to establish if any significant changes had taken place in terms of the island's network of flood embankments.

\subsubsection{Reconstruction of the 1953 source}

The shape of the tidal surge was available from data in HR Wallingford's archive. Newspaper and police reports from February 1953 indicated that the peak tidal surge level was reached at between 1.00 and 1.30 a.m. and was 4.6 metres. The breaching of the flood defences occurred shortly before the peak tidal surge was recorded.

\subsubsection{Reconstruction of the 1953 pathways}

One of the most useful sources of information was the Bodleian Library in Oxford that had maps of Canvey Island dating from 1939, 1961 and 1975. In order to recreate the 1953 flood event it was important to examine these historical maps and to assess what changes had been made since 1953 to the island's flood defence system.

Canvey Island is currently protected against flooding by a network of sea defences, comprising reinforced concrete walls and supporting structures along the waterfront, and a secondary line of earthen embankments positioned $500 \mathrm{~m}$ inland in the north and east. The defences were constructed in the 1980s and extend over $14.2 \mathrm{~km}$ from the Easthaven Barrier in the southwest to the Benfleet Barrier in the northwest. The integrity of the scheme relies upon the closure of these barriers during a major storm surge, as the defences along the western section of Canvey Island were not improved during the 1980s (Kelman, 2002).

There was little information (e.g. construction drawings, maps) available concerning the improvements to the Canvey Island flood defences that have been made since 1953. As a result it was necessary to establish the state of the 1953 flood defences from historical data and site visits. Visits to Canvey Island were useful to establish the location of the old flood defences. Information and pictures included in references by Baxter and Barsby helped to establish that there had been some secondary flood defence dikes constructed on the island between 1939 and 1953.

\subsubsection{Failure of the flood defences}

In order to develop the hydrodynamic model, the location of the breaches that occurred in 1953 needed to be established. Literature from the 1950s indicated that there were a number of breaches of the defences, however, little information was available to pinpoint exactly the location of the failures. The main source of information concerning the location of the breaches was contained in a paper produced by Allen et al in 1954. This paper outlines the dimensions of the breaches and indicates on a map the approximate locations of the failures. Baxter states that 40 breaches occurred in several places. Baxter also states that of the 58 that died during 1953, 53 of the fatalities occurred in the north-eastern part of the island where the first breaches occurred. This corresponds with the maps in Allen et al that show a number of breaches in the defences in the area adjacent to the South Benfleet Creek, the channel that divides the island from the mainland Essex in the area of Sunken Marsh.

Film from the Essex life in film archive proved a useful source of information. Newsreels from 1953 showed the aftermath of the Canvey Island flood. These newsreels were used to help provide more in-formation relating to the location and the size of the main breach in the flood defences. The various breaches in the flood defences were represented in the hydraulic model by two main openings in the flood embankments. The locations of the breaches used in the hydrodynamic model are shown in Figure 3. Based on historical information the widths of the breaches were estimated to be as follows:

- Breach 1 width $=100 \mathrm{~m}$;

- Breach 2 width $=140 \mathrm{~m}$.

\subsubsection{Construction and calibration of the hydrodynamic model}

The TUFLOW hydrodynamic model was constructed using the information described above. Canvey Island was discretised into a regular $20 \mathrm{~m} \times$ $20 \mathrm{~m}$ grid, covering a total of $18 \mathrm{~km}^{2}$. There was little information available with which to calibrate and validate the hydrodynamic model of the 1953 flood. The main source of information regarding the characteristics of the 1953 flood was contained in Allen et al. Allen et al state that a flood volume for Canvey Island of 11.7 million $\mathrm{m}^{3}$ was estimated by the Kent and Essex River Board shortly after the event. This observed data was used to calibrate the Manning's $\mathrm{n}$ roughness coefficient for the TUFLOW model of the island. Initially a Manning's $n$ value of 0.05 was used. However, it was found that using this roughness value yielded a flood volume of about 16 million $\mathrm{m}^{3}$. The Manning's $n$ value was increased to a value of 0.25 in order to take in account the presence of building, roads, and other obstructions. Using this value, the modelled volume of the 1953 flood was estimated to be 12.6 million $\mathrm{m}^{3}$. This compared well with the observed 1953 flood volume.

The results of the hydrodynamic modelling indicated that the 1953 flood covered most of the eastern part of Canvey Island. Figure 3 shows a map of the peak flood extent. The modelling indicated that the water depth was around $2 \mathrm{~m}$ to $3 \mathrm{~m}$ at the point closest to the breach, with a mean depth of between $0.8 \mathrm{~m}$ 


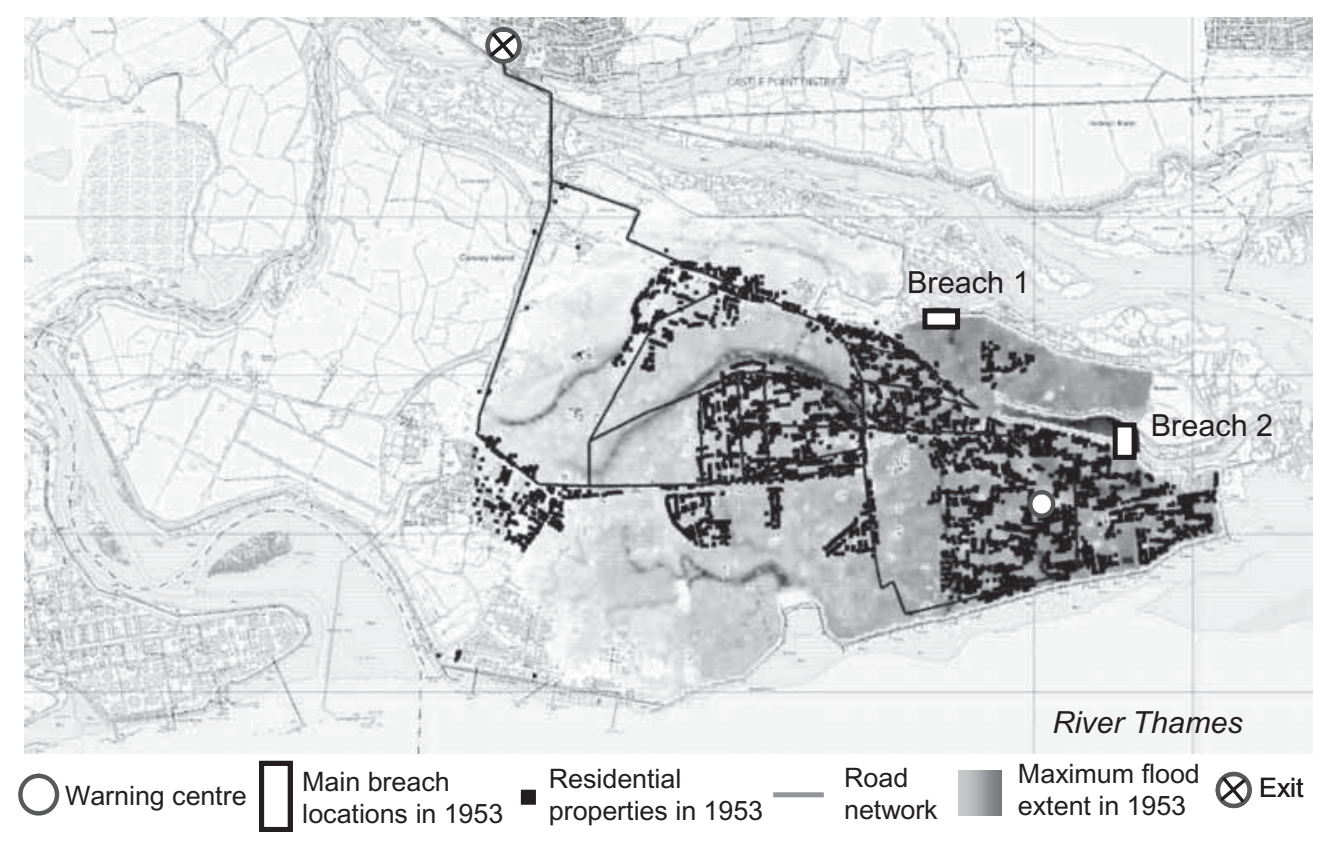

Figure 3. Maximum flood extent and location of the main breaches for the 1953 Canvey Island flood.

to $1.0 \mathrm{~m}$. The highest velocities were in the vicinity of the breaches with the peak water velocity being about $1.5 \mathrm{~m} / \mathrm{s}$. The depth and velocity results from the TUFLOW model were used as an input to model the loss of life that occurred in the 1953 flood.

\section{LOSS OF LIFE MODELLING FOR THE 1953 FLOOD EVENT}

\subsection{Introduction}

Despite the global impacts of floods there are a limited number of methods to estimate the loss of life and the evacuation times for flood events. Loss of life modelling can be performed at different levels of detail as follows:

- Macro or overall event level where one mortality rate is applied to the whole of the exposed population;

- Meso or group/zone level where mortality rates are estimated for groups of people or specific zones;

- Micro or individual level where the circum-stances and behaviour of each individual is modelled to estimate each person's probability of dying.

Until recently, most of the loss-of-life models for floods were based on a statistical analysis of fatalities and injuries from historical events. To date the work done in the UK to assess the loss of life and evacuation times for flood risk areas has been limited to macro or meso level estimates.

To provide a more accurate assessment of loss of life a model is required that utilises the best available science on how fatalities are related to the characteristics of the floodwater and that is also dynamic and allows people to interact with the flood water. In order to obtain the emergent behaviour of people during floods an agent-based model is required. An agentbased model is a computational model that simulates the interactions of autonomous receptors with a view to assessing their effects on the system as a whole. It can model the simultaneous operations of multiple "agents" or receptors (in this case people) with the floodwater, in an attempt to recreate and predict the actions of complex phenomena such as those that occur in flood emergency. In order to model loss-oflife for the 1953 flood on Canvey Island a Life Safety Model (LSM) developed by BC Hydro of Canada was used.

The LSM software is still at a developmental stage and had previously only been used to carry out dam break risk assessments for small communities (e.g. less than 3,000 people) in Canada. The LSM allows dynamic interaction between the receptors (e.g. people, vehicles and buildings) and the flood hazard. The LSM requires the following data including: 
- The location of individual properties, vehicles and people;

- Flood depths and velocities from a two dimensional hydraulic model;

- Details of the road network and other evacuation pathways

The core of the system is the LSM Simulator that requires two inputs: an initial state of the world (which describes modelling receptors such as people, buildings, cars, roads) and the flood wave. The simulator output includes an estimated of loss of life and dynamic computer-graphics visualisations (BC Hydro, 2004 and 2006).

The system models the "fate" of a set of receptors, which are described by their position at each time step through the simulation. Each receptor can have a set of properties that describes its normal location/condition during a week, such as travel times, school/work hours, and weekend activities. Other time-varying properties include the ability of the receptor to withstand the effect of the flood wave, and how it would react to the approaching wave, with and without a formal evacuation warning.

The model uses a generalised event logic to determine the location of each person, whether they are aware of the flood wave, whether they are trying to find a safe haven, what happens if they encounter the flood, and whether the person survives or not (BC Hydro, 2004 and 2006). A loss function related to each receptor (e.g. people, buildings, vehicles) specifies the ability of an receptor to resist the impact from the flood wave, in terms of depth and velocity, and how these can change during an event. There can be instantaneous loss when an individual person encounters fast-flowing water, or a group of people who have sought safety in a building can suffer cumulative loss if the building collapses or a slow deterioration in health if they are exposed to the floodwater for a significant length of time, as a result of hunger or cold.

As a flood event evolves, the interaction of receptors with the flood wave will impact the ultimate loss of life. The timing of the event and the decisions made by individuals can determine whether or not they can escape the flood wave. As the flood progresses, escape routes can be eliminated by rising water, and with advancing time roads can become congested with evacuees. Issues considered by the LSM include:

- The manner in which people at risk are located in the flood hazard zone based on the time of day, type of building;

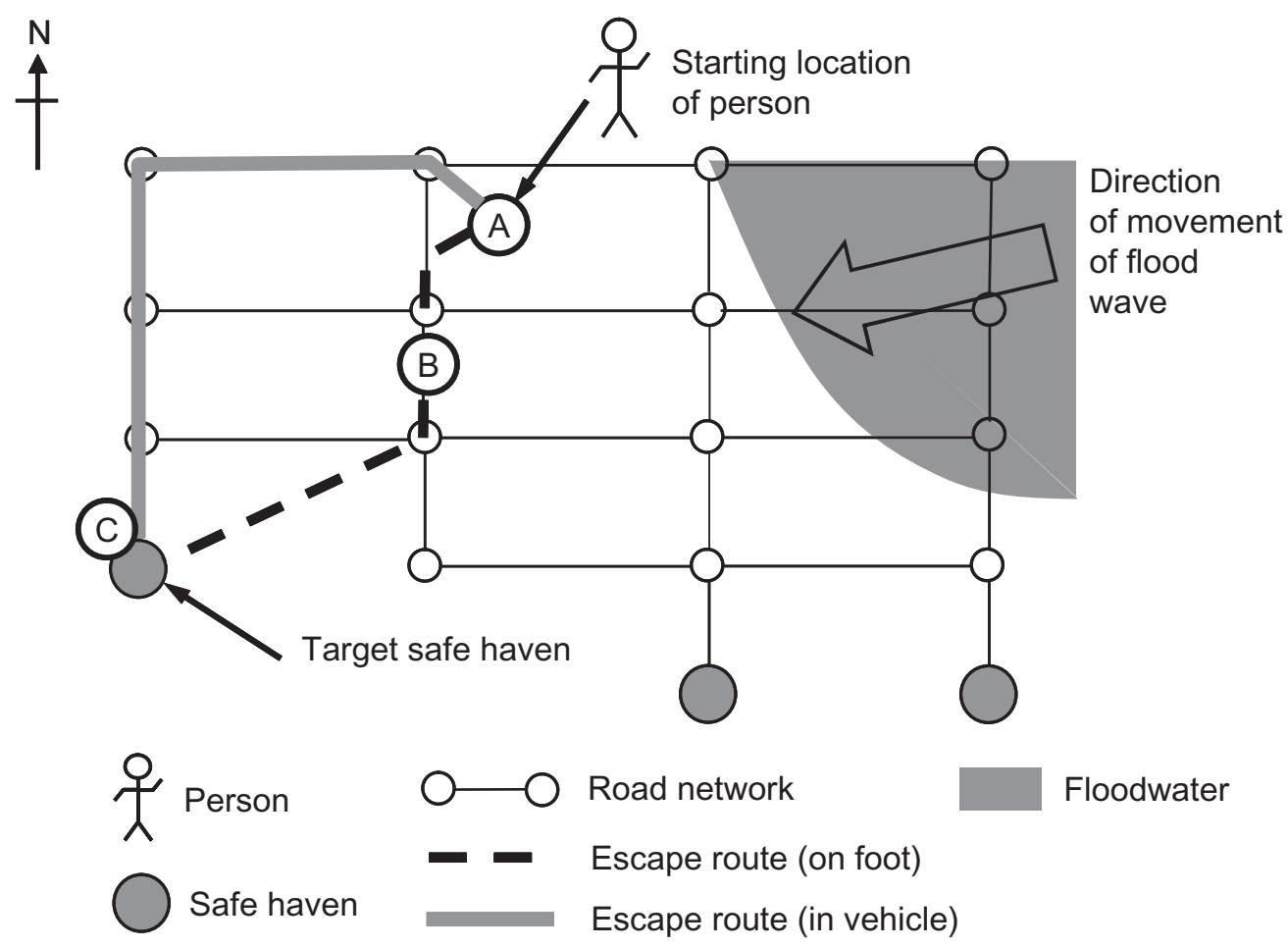

Figure 4. Fate diagram for a person in the LSM. (Source: Adapted from Johnstone et al, 2005). 
- How people move in and out of the flood hazard zone when they are unaware a flood is occurring;

- The interaction of people during the evacuation including the effect of warnings;

- The "resistance" of people to the floodwater in terms of their ability to survive;

- The state of buildings, vehicles during the flood event;

- The capacity of evacuation routes and how this impacts the loss of life.

The internal logic of the LSM can be explained by considering how an individual might experience a flood event. Figure 4 shows a person located in a building at the start of a flood event. Assuming that the area will be heavily inundated by floodwater, the person would be killed if caught in the building without warning in the position denoted by A. Three possible safe havens are shown to which the person can evacuate on foot or in a vehicle. Taking into account the "costs" to reach each haven, the southwest alternative is optimal for both foot and vehicle escape. However, if the person at-tempts escape on foot, they will be overwhelmed at point B. Under the third scenario, the person survives due to a combination of sufficient warning and the use of a vehicle to reach point $\mathrm{C}$. The ability to generate and assess the outcomes of multiple scenarios is a key capability of the LSM.

\subsection{Assessment of the location of the receptors in 1953}

To assess the loss of life for the 1953 flood a "virtual world' needs to be recreated within the LSM. This means that the location and number of people and properties that existed in 1953 needed to be established. Data from the 1951 census were used to estimate the population of the island in 1953. The population in 1953 for Canvey Island was estimated to be 12,890 . Owing to the fact that the 1953 flood occurred at 1 am on a Sunday morning the assumption was made that everybody was at home when the flood occurred and had little or no warning of the impending disaster. Historical maps from 1939 and 1961 were used to assess the distribution of the properties on the island at the time of the flood. The number of properties on the island in 1953 was estimated to be 5,218 .

\subsection{Flood warning}

Within the LSM it is possible to take cognisance of any flood warnings that occur. From the 1953 police reports and other sources it appeared that at the time the first breaches of the flood defences occurred the sirens on the island were sounded in the hope of raising the alarm. Firemen and the police also commenced warning people by going from door-todoor. The location of the warning centre is shown in Figure 3. The rate of the warning dissemination in the LSM was set about $6 \mathrm{~km} /$ hour, as this is equivalent to a fast walking pace.

\subsection{Results of the 1953 loss of life modelling}

\subsubsection{Introduction}

The results of the reconstruction of the 1953 flood event agreed well with the available historical data.

Using the default parameters in the LSM 54 fatalities as a result of drowning and 50 as a result of exhaustion (i.e. time exposed to the floodwater). The model also estimated that 197 people would die as the result of building collapsing. The LSM estimated that 130 people were "toppled" (i.e. knocked over) during the 1953 event. This number can be used as a proxy for serious injuries. The actual number of people that died in 1953 was 58. From the historical evidence available it would appear that almost all of these were as the result of drowning.

It should be noted that the LSM has been developed for use in North America where most of the building have wooden frames and are more prone to collapsing during a flood event than buildings in Europe. As result the LSM currently overestimates the number of people that will die as the result of structural failures for most European flood events.

The number of fatalities and injuries is dependent on the "resilience factors" applied to both people and buildings and other parameters such as the rate of warning. An analysis of the sensitivity of the results to various parameters was undertaken and this is discussed below.

\subsubsection{Parameter sensitivity analysis}

The sensitivity the loss-of-life for the 1953 Canvey Island flood to a number of the key parameters used in the LSM software was undertaken. These included:

i. Physical condition parameter of people;

ii. The rate of the warning dissemination;

iii. The proximity warning distance.

These are discussed below:

(i) Physical condition parameter of people Within the LSM there is a Human "Object Damage and Loss Function" (ODLF). The ODLF function determines when a person in the floodwater is "toppled" or "deceased". An individual that is "toppled" becomes immobile in the model and their strength will decline until they become so weak that the LSM considers them to be deceased or be able to move again as result of a reduction in the velocity and depth of the floodwater. 
In the LSM for a person to be considered "deceased" they either have to experience a combination of floodwater velocity and depth greater than a certain threshold known as the "drowning critical value" or their physical condition parameter (PPC) needs to decline below a certain value.

As part of the research, variations of $\pm 30 \%$ to the default physical condition (PPC) parameter were made to assess the changes in this parameter on the number of fatalities. The results of this variation in the PCC are shown in Figure 5. Figure 5 indicates that increasing the PCC has little effect on the number of fatalities that occur as a result of drowning or exhaustion. Decreasing the PPC value by $30 \%$ has little impact in the number of fatalities as a result of drowning. However, a $10 \%$ reduction in PPC doubles the numbers of modelled deaths as a result of "exhaustion" and "continuous" exposure and a 30\% decrease in PPC increases this figure from a value of 50 for the default value of PPC to 674 .

The affect of the physical condition parameter (PPC) on the percentage of the total population that reach the exit of Canvey Island eight hours after the breach of the flood defences occurred was investigated. The location defined as the "exit" to Canvey Island is shown in Figure 3. The results of this investigation are shown in Figure 6. A decrease in the PPC of $30 \%$ from the default value reduces the total percentage from almost $89 \%$ to $83 \%$. However, increasing the PPC by $30 \%$ from the default value only has a very slight impact on the percentage of the total population that reach safety within eight hours.

(ii) The rate of the warning dissemination

One of the key parameters in the LSM model that affects the awareness of people that a flood event is occurring and as a consequence the number of fatalities is the rate at which a flood warning is disseminated. The LSM allows warning centres to be set up and the warnings are disseminated radially. The location of the warning centre is important and can affect the results of the loss-of-life modelling. For the reconstruction of the Canvey Island 1953 event the warning centre in the model was located at the police station. The location of the warning centre is shown in Figure 3.

Figure 7 shows how the number modelled of fatalities for the 1953 flood relates to the warning rate. It is interesting to note that the number of fatalities decrease with an increase in the warning dissemination rate until the warning dissemination rate exceeds approximately $0.7 \mathrm{~km} / \mathrm{hour}$ after which the number of fatalities remains constant. The warning location centre is in the centre of Canvey Island's most populous area. Within in one hour of the eastern breach occurring most of the population at risk will be aware that a flood is occurring. It is postulated that an increase in the warning dissemination rate above $0.7 \mathrm{~km} /$ hour will not lead to the number of fatalities reducing owing to the limited capacity of the evacuation routes that act as a "bottleneck" to people leaving the area at risk.

(iii) The proximity warning distance

The proximity warning distance represents the maximum distance over which two people can communicate a warning to each other. This means a person in the model who is aware that a flood is happening can alert someone who is unaware a flood is taking place if the distance between the two people is less than the "proximity warning distance". A proximity warning distance of 0 means that a person who is aware a flood event is unfolding cannot warn a person who is unaware of the flood no matter how close to them that they are located. Figure 8 shows the affect of the proximity warning distance on the number of fatalities. It is interesting to note that the fatalities that result from drowning and exhaustion are not as sensitive to the proximity warning distance as those that result from the collapse of buildings. This is because when the proximity warning distance is low people tend to remain in their houses, so that when they collapse there is an instantaneous loss-of-life. As previously stated the LSM was developed for use in North America, where generally houses are less resilient to floodwater. As a result the number of buildings that collapse in the LSM is likely to be overestimated.

\section{CONCLUSIONS}

A TUFLOW hydrodynamic and loss-of life model were applied to Canvey Island to model the Great North Sea flood of 1953. The TUFLOW model showed that the 1953 flood covered most of the eastern part of Canvey Island and the mean depth of the floodwater was about $1 \mathrm{~m}$. Observed floodwater volumes from the 1953 flood were used to calibrate the TUFLOW model. The velocity and depth grids from the hydrodynamic model were used as input to a Life Safety Model (LSM).

The LSM was used to model each of the 13,000 people living Canvey Island in 1953 and their response to the flood wave. The 54 fatalities predicted by the LSM as a result of drowning for the 1953 event compared well with the 58 observed fatalities, most whom died in this way. The LSM has been developed for use in North America where most residential properties are constructed from wood. For a European situation it was found that the LSM generally overestimates the number of buildings that are likely to collapse during a flood event. As a result the LSM estimated that approximately 200 people died during the 1953 flood as a result of structural failure of their homes. It was 


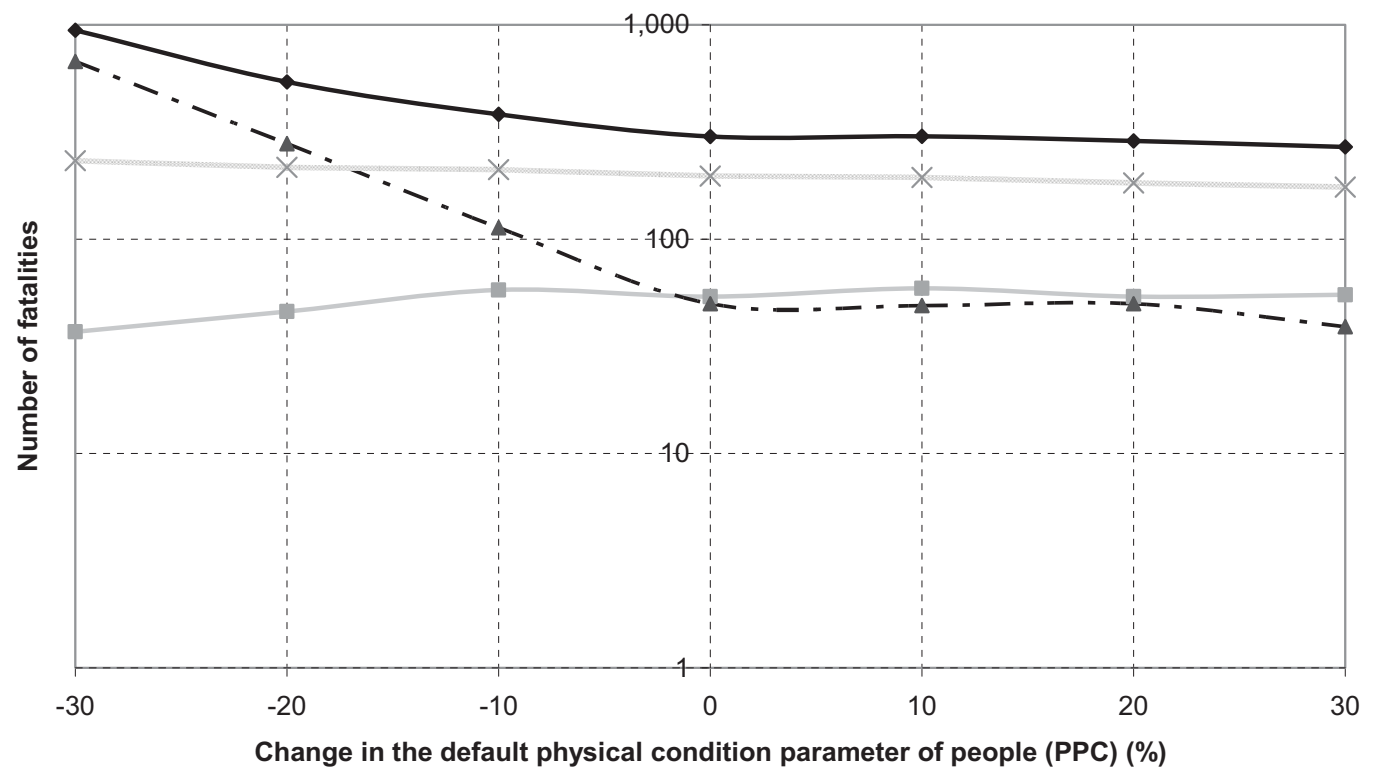

$\multimap-$ Total fatalities $\because-$ Deaths - Drowning $\_-\Delta-$ Deaths - Exhaustion $\times$ Deaths - Building collapse

Figure 5. Effect of changes in the LSM default physical condition parameter of people and its effect on the number of modelled fatalities for the 1953 Canvey Island flood.

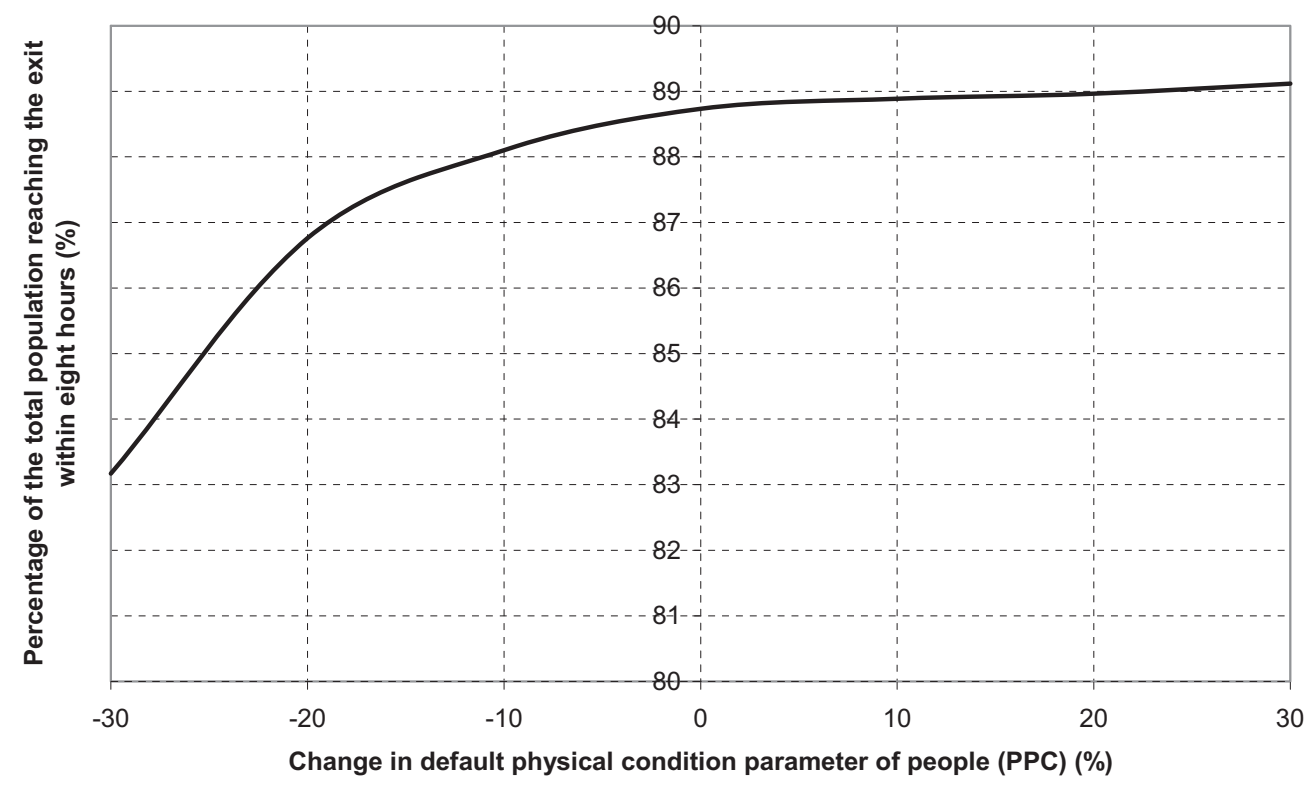

Figure 6. Effect of changes in the LSM default physical condition parameter of people and its effect on the percentage of people reaching the exit for the 1953 Canvey Island flood eight hours after the breach of the flood defences. 


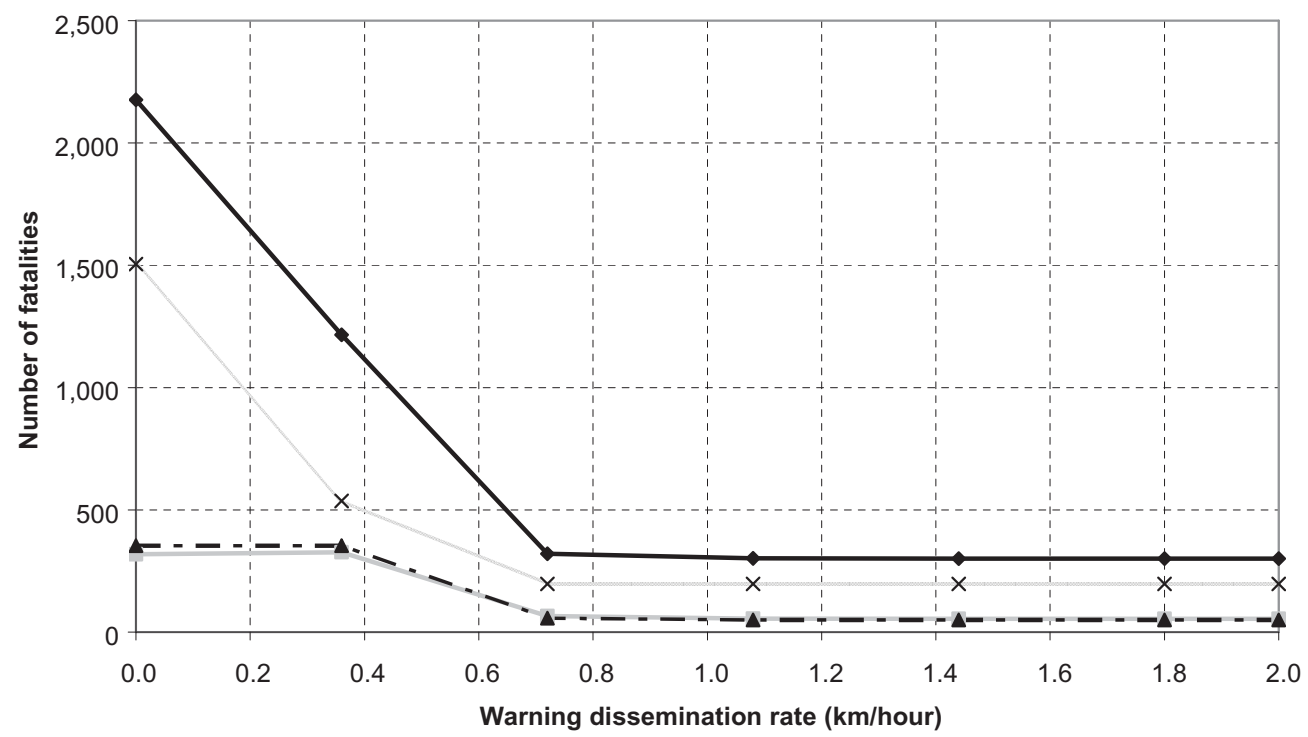

$\rightarrow$ Total fatalities $\rightarrow$ Deaths - Drowning $\rightarrow \mathbf{A}$ - Deaths - Exhaustion $\times$ X Deaths - Building collapse

Figure 7. Effect of changes in the warning dissemination rate and the number of fatalities for the 1953 flood event.

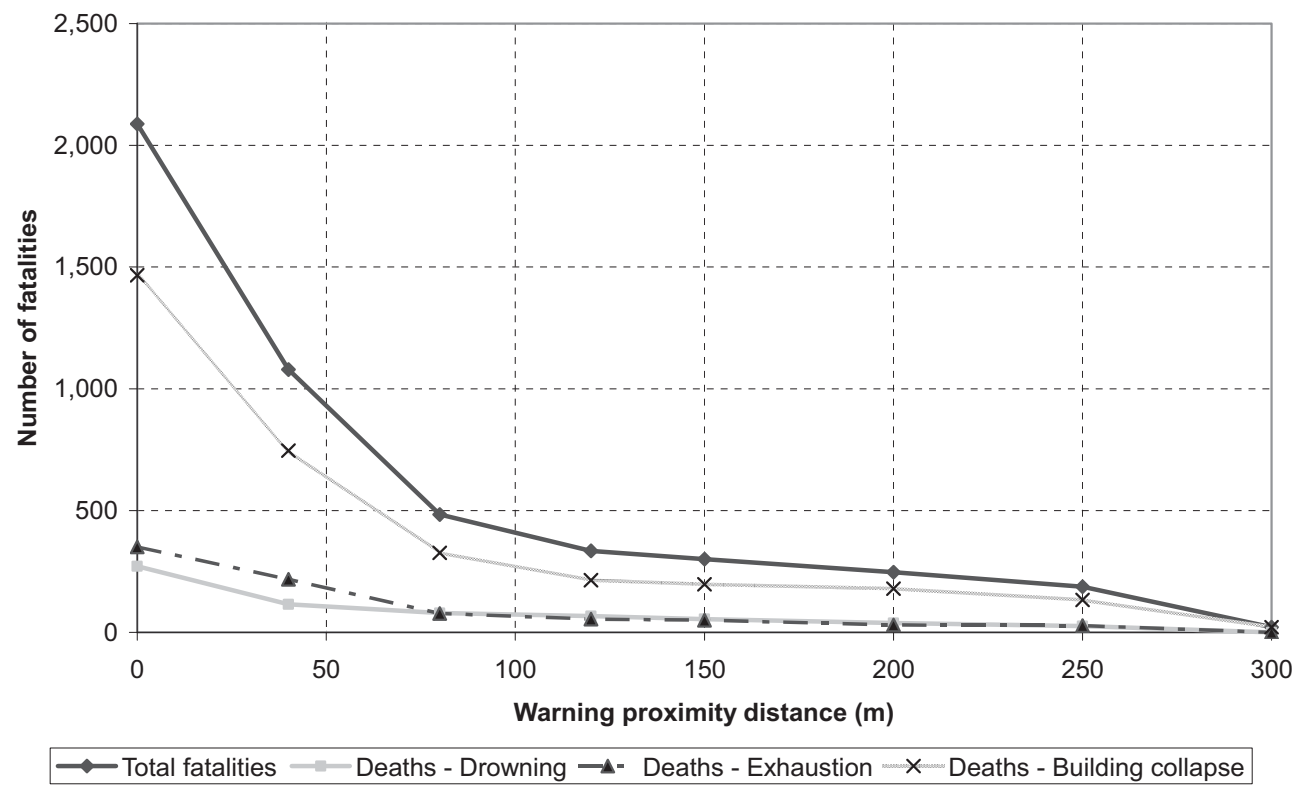

Figure 8. Effect of changes in the warning proximity distance and the number of fatalities for the 1953 flood event. 
concluded that the LSM currently underestimates the resilience to floodwater of most European housing stock and overestimates the number of people who die instantaneously when their houses collapse.

Once the LSM has been set up, it is relatively simple to make changes to the model to assess the impact of different interventions and management strategies on loss of life. As part of the research the effect of different flood warning dissemination rates and the physical condition of people on the number of fatalities was investigated. The research showed that in the future the LSM could be used to assess the effectiveness of new evacuation routes, flood warning systems and safe havens in reducing the potential loss-of-life within areas at risk of flooding. The LSM also allows evacuation times to be assessed.

It was found that the LSM offers a scientifically robust method of assessing the residual risk behind flood defences and downstream of dams in terms fatalities. The LSM model is the only loss-of-life model currently that has a dynamic interaction between the receptors (e.g. people, vehicles) at risk and the flood hazard. Other loss-of-life models generally only provide first order of magnitude estimates of fatalities and do not include a spatio-temporal modelling which is crucial to assessing the number of flood fatalities accurately. These may be useful for high level planning but are unlikely to be helpful for detailed emergency planning, flood defence or dam break assessments.

At present in the UK, flood incident management and emergency plans take little or no account of the risks to life and evacuation times. Given the age of flood defences and increasing flood levels as a result of climate change there is a need to assess these accurately. The outputs from accurate, dynamic loss-of-life models can help the Environment Agency, planners and the emergency services to improve their planning and response to major flood incidents and that this will assist in reducing the probability of loss of life. Future development work is planned to further tailor the LSM to a European environment. This will further improve the accuracy and the robustness of the results.

\section{ACKNOWLEDGMENTS}

The work described in this publication was supported by the European Community's Sixth Framework Programme through the grant to the budget of the integrated Project FLOODsite, Contract GOCE-CT2004-505420. This paper reflects the authors' views and not those of the European Community. Neither the European Community nor any member of the FLOODsite consortium is liable for use of the information in this paper. The authors also wish to thank
BC Hydro and the Canadian Hydraulics Center for their assistance and permission to use the LSM software on this study.

\section{REFERENCES}

Allen, F., Price, W., Inglis, C., 1954. Model experiments on the storm surge of 1953 in the Thames Estuary and the reduction of future surges. In Proceedings of the Institution of Civil Engineers, Vol 4 Pt III, pp 48-82.

Baxter, P., 2003. The East Coast Big Flood Programme, 31 January to 1 February 1953: Human impacts and mitigation of North Sea storm surge floods A summary of the human disaster, Philosophical transaction of the Royal Society, Vol 363, pp 1293-1312.

Barsby, G., 2001. Canvey Island, Tempus Publishing Limited, Gloucestershire, UK

Brown, J., Spencer, T. \& Moeller, I. 2007 Modeling storm surge flooding of an urban area with particular reference to modeling uncertainties: A case study of Canvey Island, United Kingdom Water Resources Research, Vol. 43, W06402, doi:10.1029/2005 WR004597, 2007

BC Hydro, 2004 Life Safety Model (LSM) formal description engineering report E299, October 2004

BC Hydro, 2006 Life safety modelling environment V2.0 beta User manual, August 2006

Canvey Island archive site, 2008 [WWW] http://canveyisland.org.uk/ (Accessed 12 June 2008)

Canvey Island history in words and history, 2008 [WWW] http://www.canveyislandhistory.com/history.htm (Accessed 12 June 2008)

Defra, 2005 R\&D outputs: Flood Risks to People Phase 2 FD2321/TR1 The Flood Risks to People Methodology, March 2005

East Anglian film archive, 2008 Moving history - A guide to UK film and television archives in the public sectorEssex floods 1953

Elford, D. We are in for a High Tide Tonight, Essex Police Museum History Notebook, Issue 27

Essex life in film archive, 20081953 film of Canvey Island [WWW] http://essexlife.e2bn.org/cif_af.htm (Accessed 12 June 2008)

Johnstone, W.M., Sakamoto, D., Assaf, H. and Bourban, S. 2005. Architecture, modelling framework and validation of BC hydro's virtual reality life safety model. ISSH, Stochastic Hydraulics 23-24

Jonkman, B., 2007 Loss of life estimation in flood risk assessment - Theory and applications Dissertation submitted for the degree of Doctor of Philosophy, June 2007, Technical University of Delft, The Netherlands

Kelman, I., 2002. Physical Flood Vulnerability of Residential Properties in Coastal, Eastern England, PhD Dissertation for the degree of Doctor of Philosophy.

Lumbroso, D., Gaume, E., Logtmeijer, C., Mens, M. \& van der Vat, M, 2008 Evacuation and traffic management, FLOOsite Task 17 report number T17-07-02, March 2008

Open University/BBC, 2008 Flooded Britain [WWW] http:// www.open2.net/floodedbritain (Accessed 12 June 2008)

TUFLOW, 2008 Flood and tide simulation [WWW] http:// www.tuflow.com/ (Accessed 12 June 2008) 


\title{
Fluid thinking...smart solutions
}

HR Wallingford provides world-leading analysis, advice and support in engineering and environmental hydraulics, and in the management of water and the water environment. Created as the Hydraulics Research Station of the UK Government in 1947, the Company became a private entity in 1982, and has since operated as a independent, non profit distributing firm committed to building knowledge and solving problems, expertly and appropriately.

Today, HR Wallingford has a 50 year track record of achievement in applied research and consultancy, and a unique mix of know-how, assets and facilities, including state of the art physical modelling laboratories, a full range of computational modelling tools, and above all, expert staff with world-renowned skills and experience.

The Company has a pedigree of excellence and a tradition of innovation, which it sustains by re-investing profits from operations into programmes of strategic research and development designed to keep it - and its clients and partners - at the leading edge.

Headquartered in the UK, HR Wallingford reaches clients and partners globally through a network of offices, agents and alliances around the world.

\section{HR Wallingford}

Working with water

\author{
HR Wallingford Ltd \\ Howbery Park \\ Wallingford \\ 0xfordshire 0X10 8BA \\ UK
tel $\quad+44(0) 1491835381$
fax +44 (0)1491832233
email info@hrwallingford.co.uk

\section{www.hrwallingford.co.uk}

